This preprint version may not exactly replicate the published version.

Published in: Blanuša, J., Barzut, V., Krstić, D. \& Hilčenko, S. (2021). Effects of Preschool Teachers' Training and Practice on The Attitudes Toward Giftedness. In Herzog, J. (Ed.), Giftedness in a Variety of Educational Fields (pp. 31-42). Hamburg: Verlag dr. Kovač.

\title{
Effects of Preschool Teachers' Training and Practice on The Attitudes toward Giftedness
}

\author{
Jelena Blanuša ${ }^{1}$, Vesna Barzut ${ }^{2}$, Dijana Krstić ${ }^{1} \&$ Slavoljub Hilčenko ${ }^{1}$ \\ ${ }^{1}$ College for Vocational Education of Preschool Teachers and Coaches, Subotica, Serbia \\ ${ }^{2}$ Faculty of Sport and Tourism, Educons University, Novi Sad, Serbia
}

\begin{abstract}
This study examined effect of preschool teachers' training and practice on the attitudes toward giftedness. Attitudes toward gifted were measured by "Opinions about the gifted and their education". Total of 163 participants took part in the study (41 preschool teachers; 67 students and 55 sport trainer students)

Result of MANOVA showed no significant difference between three groups, while univariate results showed differences on Needs and support $(F(2,160)=7.71, p<0.01)$ and Social value $(F(2,160)=3.08, p<0.05)$ scales, where they were most valued by preschool teachers, then by students, and least valued by sport students. Explanation could be that teachers learn to value the gifted during education and practice. Prejudices and rejection of the gifted, remain moderately high and unaffected by education.
\end{abstract}

Keywords: gifted education, practice, attitudes, preschool education

\section{Introduction}

The concept of giftedness has come a long way since first serious research of gifted children. Logically, the understanding and knowledge increased during the time, but there are still many open questions to be answered. At the beginning, the giftedness was mainly seen as high intellectual abilities. One the best known longitudinal study 
conducted by Terman (Terman, 1925 cited in Winner, 2000) followed 1528 kids with above average intelligence (average score was 151). Contrary to expectations, none of these kids achieved some extraordinary intellectual or creative accomplishment. They were successful, well-adapted, but nothing more. This study has shown that, although important, IQ is not the only criteria that define giftedness.

Nowadays, we know that gifted kids are not super-humans, superior in each domain. In fact, it was shown that many gifted kids have uneven development of cognitive, emotional and social aspects. This phenomenon is known as internal asynchrony. Parents and teachers who are not aware of this phenomenon most likely will not be able to provide sufficient and adequate support for gifted kids (for details, see Barzut, 2017). Not just that one gifted kid could be advanced in one area and completely average or below average in others, it was also shown that gifted kids could also have learning difficulties (dyslexia or dyscalculia) and developmental issues (ADHD, autistic and sensory processing problems) (Web, 2000). Those kids are called twice-exceptional kids and they are facing many challenges in the educational process. Sometimes their giftedness is not properly recognized because their learning or developmental issues seems prominent, but also, some kids are relying on own giftedness which masks their learning and developmental issues. Correct identification is crucial for understanding and preventing negative teachers' and parents 'attitudes.

Identification and education of gifted kids

Correct identification of kid's weaknesses and strengths is essential it is only the first step. Gifted students require special support in order to achieve their full potential. However, it is questionable whether teachers and parents can correctly identify gifted kid, especially at an early age. Blanuša and colleagues (Blanuša, Rodić \& Knežević, 2020) reported that preschool teachers weren't successful at all in the identification of intellectually gifted kids age 5 to 6.5 years.

In the past decades, several programs for the education of the gifted were developed and evaluated. Different programs emphasize on different aspects that are considered the most important. For example, inclusive classroom is often considered the best environment for social-emotional development, while special schools (such as art school) are the best for nurturing the specific talents, etc. 
It is interesting to know that researches among the globe showing consistent, negative results regarding teachers' self-evaluation for preparedness for working with gifted children. Teachers are not properly educated for working with gifted children (Archambault et al., 1993, Barzut \& Blanuša, 2015), moreover, it seems that they also are not following a current recommendation and research from relevant field. For example, a study conducted in Serbia (Barzut \& Blanuša, 2015) showed that teachers the least preferred acceleration, although numerous studies are showing that this could be the most effective program for gifted children (for review see Blanuša \& Barzut, 2020). Teachers' knowledge about different programs and their effects clearly could determine whether they will propose some particular intervention. For example, even Serbian law recognizes acceleration and provide some regulation for it. Despite this, these measures are rarely used in practice (Barzut \& Blanuša, 2020).

\section{Teachers' attitudes toward gifted}

Although teachers mostly recognize the need for providing adequate support in the education of the gifted ones, various studies showed that gifted individuals are often recognized as unadapted, elitists and persons with special privileges by their environment.

Ambivalent attitudes toward gifted and education of gifted is well documented (e.g. Begin \& Gagne, 1994). The same authors also stated that most research showed a lack of consensus regarding need of gifted and consequently about educational intervention. The inconsistency in results is explained by these authors by different operationalization and different methodology that has been used in different studies.

However, Gagné and Nadeau's (1991) study also reported mixed results: positive, ambivalent or even negative attitudes toward gifted students and gifted education. It seems that teachers have positive attitudes toward special needs and support for gifted kids while they often have negative attitudes toward acceleration. Finally, attitudes toward ability grouping are ambivalent (for details, see Perković Krijan \& Borić, 2015). One of potential factors that could determine attitudes toward gifted is teachers' education in relevant field. One study conducted in Australia (Lassig, 2009) showed that teacher-training and school involvement in gifted education result in more positive attitudes toward gifted. At the other hand, education for working with gifted students 
might not always result in more positive attitudes toward gifted. One study (McCoach, \& Siegle, 2007) shown that education can influence attitude also in opposite direction.

\section{Definition of reasearch problem}

Knowing that teachers most likely didn't have the proper education for working with gifted students, they are not informed about new findings from the area of giftedness (Barzut \& Blanuša, 2015) it is reasonable to assume there are possibilities for misconception and negative attitudes toward gifted.

\section{Purpose and goals}

This study aimed to examine whether education and practice are improving teachers' understanding of the needs of gifted. Identification of common misconceptions about giftedness and gifted students will not just increase knowledge about this important topic but also could be starting point for developing better, comprehensive curriculum for students and teachers who are already working with the gifted.

\section{Methods}

Hypotheses and research questions

The main question in our study was to determine whether education and practice can influence attitudes toward gifted students.

Based on the prior research, our hypothesis was that preschool education and practice increase positive attitudes to the needs of gifted and support for them, while prior education cannot influence prejudices and particular knowledge about programs for gifted students.

\section{Research methods}

Three main groups of participants were made to represent different levels of education and practice in preschool education. The first experimental group (with both education and practice factor present) has consisted of preschool teachers. The second experimental group included preschool teacher students, currently involved in higher education and with no official practice (only education factor present). The control group consisted of 
sport trainer students with the same level of education in another field (with no education and no practice).

Dependent variable in research was attitudes toward giftedness. It can be divided in 6 subfactors, grouped in three main categories: Attention to gifted students (Needs and support and Social value scale), Prejudice (Resistance to objections and Rejection) and Knowledge about programs (Ability grouping and School acceleration).

\section{Research sample}

Overall, 163 participants took part in the study, 43 males and 117 females, age from 18 to 58 years. There were three main groups. The first experimental group consisted of 41 preschool teachers ( 1 male and 40 females, mean age $41.78, \mathrm{SD}=9.73$ ) working in kindergarten "Naša radost" in Subotica. The second experimental group was made by 67 preschool-teacher students ( 5 males and 62 females, mean age 22.41, SD = 7.89) from the College for vocational studies for preschool teachers and coaches, Subotica. For the control group, 55 sport trainer students (40 males and 15 females, mean age 20.67, SD = 5.01) from the same college were chosen.

\section{Analysis of measuring instruments}

Attitudes toward gifted were measured by "Opinions about the gifted and their education" (Gagne \& Nadeau, 1991) consisted of 34 items measuring attitudes toward gifted on 5-point scale (from "totally disagree" to "totally agree"). It consisted of six main scales. High scores on Needs and support express someone's opinion that gifted students have special needs and require additional institutional support (item example: "Our schools should offer special educational services for the gifted"). Resistance to objections expresses negative attitudes about gifted ("Gifted children might become vain or egotistical if they are given special attention"). Social value measures someone's view of the usefulness of gifted ("Gifted persons are a valuable resource for our society"). Rejection scale refers to social isolation of gifted ("Often, gifted children are rejected because people are envious of them"). Ability grouping scale expresses support for the idea of making special classes for gifted based on ability grouping ("The best way to meet the needs of the gifted is to put them in special classes") and School acceleration supports faster passing thought school curriculum than usual ("A greater number of gifted children should be allowed to skip a grade"'). 
The questionnaire was translated in the Serbian language with permission of authors, and it showed satisfying metrical characteristics in this study (Cronbach's $\alpha=0.77$ )

\section{Procedure}

First part of the study was conducted during General psychology course with three subsequent generations of students in winter semesters 2017, 2018 and 2019. During the class, preschool teachers and coach students filled the questionnaire. They have received course credits for their participation.

Second part of the study was carried out in spring 2018, in the various objects of the Preschool "Naša radost" in Subotica. Preschool teachers from different groups were asked to fill the same questionnaire.

\section{Results}

Results of multivariate analysis of variance showed no significant difference between three groups. In general, preschool teachers, preschool students and coach students gave similar answers to the questionnaire. Preschool education and practice do not have any effect on general attitude toward gifted.

Nevertheless, when considering univariate tests for each scale separately, ANOVA analysis revealed some differences in two of them. There were significant differences on Needs and support $(\mathrm{F}(2,160)=7,71, p<0.01)$ and Social value $(\mathrm{F}(2,160)=3.08, p<0.05)$ scales. Preschool teachers obtain the highest main scores, followed by preschool teacher students, and coach students had the lowest scores on both scales (for details see Table 1). However, posthoc tests showed that the only significant differences appear between actual preschool teachers and coach students (control group), and no between other groups. The described pattern of results was obtained for both Need for support (Bonferroni, $p<0.01$ ) and for Social value scale (Bonferroni, $p<0.05$ ). There were no significant differences between preschool teacher students and actual preschool teachers, nor between preschool teacher students and coach students.

Table 1. Significant ANOVA results for variables Needs and support and Social value (left) followed by descriptive statistics in three different education groups (right).

\begin{tabular}{cccc} 
Presch & Presch & Coach & Total \\
ool & ool & studen & \\
\hline
\end{tabular}




\begin{tabular}{|c|c|c|c|c|c|c|c|c|}
\hline & & & & & $\begin{array}{c}\text { teacher } \\
\mathrm{s}\end{array}$ & $\begin{array}{c}\text { studen } \\
\text { ts }\end{array}$ & ts & \\
\hline & SS & $d f$ & $\mathrm{~F}$ & $p$ & & Mear & (SD) & \\
\hline $\begin{array}{l}\text { Needs and } \\
\text { support }\end{array}$ & 7.30 & $2(60)$ & 7.71 & 0.01 & $\begin{array}{c}3.96 \\
(0.57)\end{array}$ & $\begin{array}{c}3.7 \\
(0.73)\end{array}$ & $\begin{array}{c}3.41 \\
(0.72)\end{array}$ & $\begin{array}{c}3.67 \\
(0.72)\end{array}$ \\
\hline Social value & 1.90 & $2(60)$ & 3.09 & 0.048 & $\begin{array}{c}3.48 \\
(0.51)\end{array}$ & $\begin{array}{c}3.34 \\
(0.47)\end{array}$ & $\begin{array}{c}3.2 \\
(0.67)\end{array}$ & $\begin{array}{c}3.33 \\
(0.56)\end{array}$ \\
\hline
\end{tabular}

It is indicative that none of the groups showed extremely positive or extremely negative attitude (scores above 4 or below 2 ) on any of the scales.

\section{Discussion}

The main goal of presented study was to examine the influence of preschool education and practice on attitudes toward gifted children. To differentiate influence of practice and education, we used three groups of participants: preschool teachers, preschool teacher students, and sport trainer students.

All groups showed moderate attitudes toward gifted children and their education. The difference between groups only appeared on Social value and Need and support scales: actual teachers valued gifted children and consider additional support for them more than any group of students. It could indicate that practice in preschool system influence building positive attitudes toward gifted. Another factor that influences teachers' positive attitude could also be an education - there were no difference between preschool teachers and students. Those results are consistent with the literature (Lassig, 2009).

A possible reason for lack of differences between preschool teacher students and coach students in this study could be insufficient time of engagement in higher education: most of the students were on the first year of the study and they did not receive education about gifted students at that time.

It is also important to discuss scales where no differences appeared between the groups. On two scales which represent negative attitudes (Resistance to objections and Rejection) all groups performed equally - with main scores at about 3. It can be considered as ambivalent or lower - preschool teachers, students, and coaches have 
slightly negative attitude. They find that gifted students sometimes can be overrated and hard to adapt in their social environment.

For remaining two scales, Ability grouping and School acceleration there were no between group differences: all groups had slightly negative attitude about those programs and interventions.

Taking altogether, it seems that preschool teachers learn to value the importance of gifted through education and practice, and that made them prepared to put additional attention to gifted students. Nevertheless, moderately negative views about better opportunities for gifted than to other students, and social maladaptation of gifted ones stay unaffected. It could be interpreted in a more general manner: teachers learn to value and pay attention to gifted, but their prejudices about gifted personal and social traits remains. The results confirmed ambivalence priory described in literature (Begin \& Gagne, 1994; Gagné and Nadeau, 1991).

Teachers did not find any of the programs for gifted as especially valuable. This view is opposite to the recommendations that we could find in literature, where both ability grouping and acceleration are considered as highly effective (for review see Blanuša \& Barzut, 2020). Our result showed that neither preschool training nor expertise build positive attitudes to recommended programs. In fact, we found teachers attitudes as intuitive and intact by experience. It is consistent with self-reports given in prior study (Barzut \& Blanuša, 2015) with teachers in Republic of Serbia: they emphasize the need for additional education about giftedness, and find their knowledge about different programs as insufficient. Also, it is consistent with past research (Perković Krijan \& Borić).

Finally, possible limitation of this study can be the fact that we examined attitudes of students who are at the beginning of the higher education process. In order to examine the overall effect of education on perception of giftedness, comparing students in their final year of study could be better approach.

\section{Conclusion}

In conclusion, some important recommendations can be drawn from our research. Higher education in preschool teaching, together with practice, may be achieving its main goal: future teachers learn to pay attention to gifted individuals and to respond to their needs. But it seems that current education does not affect unconscious attitudes 
about personal traits of the gifted: they are still perceived as unadapted and asocial. In order to overcome this negative effect on giftedness education, future courses should focus more on personal traits of gifted individuals. It also should enable insight in prejudices that future teachers have, and to warn of the possible consequences of them. Additionally, proper education should present and discuss about different programs for gifted and their empirical effectiveness. If teachers have sufficient information, it is reasonable to expect that they would value themselves more and that they would have more confidence in their practice.

\section{Bibliography}

Archambault, F. X., Westberg, K. L., Brown, S. W., Hallmark, B. W., Emmons, C. L. \& Zhang, W., (1993). Regular Classroom Practices with Gifted Students: Results of a National Survey of Classroom Teachers (Research Monograph 93102). Storrs, CT: The National Research Center on the Gifted and Talented.

Barzut, V. \& Blanuša, J. (2020). Approaches to Education of Gifted Students in the Republic of Serbia. In S. Hilčenko (eds.), Collected Papers from the 11. International Interdisciplinary Scientific Conference: "Horizons" 2020, Full paper. Subotica: College of Vocational Studies, Subotica Vocational Training of Preschool Teachers and Sports Trainers.

Barzut, V. (2017) Sindrom unutrašnje disinhronije darovitih, posledice i implikacije na obrazovanje darovitih. 23. okrugli sto: Darovitost $i$ kreativni pristupi učenju, Zbornik radova, Vršac.

Barzut, V., Blanuša, J. (2015). Pristupi obrazovanju darovitih učenika i procena trenutnog stanja kroz stavove stručnjaka. Pedagogija. 70(1), 73-83.

Bégin, J., \& Gagné, F. (1994). Predictors of attitudes toward gifted education: A review of the literature and a blueprint for future research. Journal for the Education of the Gifted, 17(2), 161-179.

Blanuša, J. \& Barzut, V. (2020). Education of Gifted Children: The Review of Different Approaches and Interventions. In S. Hilčenko (eds.), Collected Papers from the 11. International Interdisciplinary Scientific Conference: "Horizons" 2020, Full paper. Subotica: College of Vocational Studies, Subotica Vocational Training of Preschool Teachers and Sports Trainers. 
Blanuša, J., Rodić. N. i Knežević, J. (2019). Efficacy of preschool teachers in detecting intellectually gifted children. Paper presented at the 25. Scientific conference Empirical Studies in Psychology, March 29 $9^{\text {th }}-31^{\text {st }}$. Beograd, Srbija. Book of abstracts, pp. 63.

Brody, L., E. \& Mills, C., J. (1997) Gifted children with learning disabilities: A review of the issues. Journal of Learning Disabilities 30(3): 282-286

Gagné, F., \& Nadeau, L. (1991). Opinions about the gifted and their education. Montréal: GIREDT Center, Université du Québec á Montréal.

Lassig, C. (2009). Teachers' attitudes towards the gifted: The importance of professional development and school culture. Australasian Journal of Gifted Education, 18(2), 32-42.

McCoach, D. B., \& Siegle, D. (2007). What predicts teachers' attitudes toward the gifted?. Gifted child quarterly, 51(3), 246-254.

Perković Krijan, I., \& Borić, E. (2015). Teachers' attitudes towards gifted students and differences in attitudes regarding the years of teaching. Croatian Journal of Education: Hrvatski časopis za odgoj i obrazovanje, 17(Sp. Ed. 1), 165-178.

Webb, J. T. (2000). Mis-Diagnosis and Dual Diagnosis of Gifted Children: Gifted and LD, ADHD, OCD, Oppositional Defiant Disorder. In Neihart, M. (ed.) Symposium on "Cutting Edge Minds: What it Means to be Exceptional".

Winner, E. (2000). Giftedness Current Theory and Research. Current Directions in Psychological Science, 9(5), 153-156. 